\title{
Atherogenic Diet Increases Cholesteryl Ester Transfer Protein Messenger RNA Levels in Rabbit Liver
}

\author{
Elaine M. Quinet, Luis B. Agellon, Paul A. Kroon, Yves L. Marcel, Yi-Chun Lee, Mary E. Whitlock, and Alan R. Tall \\ Department of Medicine, Columbia University College of Physicians and Surgeons, New York, New York 10032
}

\begin{abstract}
Cholesteryl ester transfer activity is increased in plasma of cholesterol-fed rabbits. To investigate the mechanisms leading to changes in activity, we measured cholesteryl ester transfer protein (CETP) mass by RIA and CETP mRNA abundance by Northern and slot blot analysis using a human CETP cDNA probe in control $(n=8)$ and cholesterol-fed rabbits $(n=10)$. Cholesterol feeding (chow plus $0.5 \%$ cholesterol, $10 \%$ corn oil) for $30 \mathrm{~d}$ increased CETP mass in plasma 3.2-fold in the cholesterol-fed rabbits $(12.45 \pm 0.82 \mu \mathrm{g} / \mathrm{ml})$ compared with controls $(3.86 \pm 0.38 \mu \mathrm{g} / \mathrm{ml})$. In the hypercholesterolemic rabbit, liver CETP mRNA levels were increased 2.8 times control mRNA levels. Actin, apo E, lecithin-cholesterol acyltransferase, and albumin mRNA abundances were unchanged. In contrast to the widespread tissue distribution in humans, CETP mRNA was not detected in extrahepatic tissues of either control or cholesterol-fed animals. Using a sensitive RNase protection assay, the increase in liver CETP mRNA was detectable within $3 \mathrm{~d}$ of beginning the high cholesterol diet. Thus, in response to the atherogenic diet there is an early increase in liver CETP mRNA, probably causing increased CETP synthesis and secretion, and increased plasma CETP. The results indicate that the CETP gene may be regulated by diet-induced changes in lipid metabolism. (J. Clin. Invest. 1990. 85:357363.) atherosclerosis $\bullet$ hypercholesterolemia $\bullet$ lipid metabolism - lipid transfer protein regulation • lipoproteins
\end{abstract}

\section{Introduction}

Cholesteryl ester transfer protein (CETP) ${ }^{1}$ transfers cholesteryl esters (CE) from HDL and LDL to triglyceride-rich lipoproteins (chylomicrons and VLDL). Since chylomicrons and large VLDL are rapidly removed by the liver by a putative chylomi-

Dr. Kroon's present address is University of Queensland, Brisbane, Queensland, Australia. Dr. Marcel's present address is Clinical Research Institute of Montreal, 110 Pine Ave., West Montreal, Quebec, Canada H2W 1 R7.

Address correspondence to Dr. Tall, Department of Medicine, Columbia University College of Physicians and Surgeons, 630 W. 168th St., New York, NY 10032. 1989.

Received for publication 5 June 1989 and in revised form 9 October

1. Abbreviations used in this paper: CE, cholesteryl ester; CETP, cholesteryl ester transfer protein; LCAT, lecithin:cholesterol acyltransferase.

J. Clin. Invest.

(C) The American Society for Clinical Investigation, Inc.

0021-9738/90/02/0357/07 \$2.00

Volume 85, February 1990, 357-363 cron remnant receptor (1), the CETP provides a mechanism for returning $\mathrm{CE}$, formed in $\mathrm{HDL}$ by the lecithin:cholesterol acyltransferase (LCAT) reaction, to the liver. This provides a pathway for returning plasma $\mathrm{CE}$ to liver, which can function independently of liver LDL receptor-mediated clearance (2). Although this pathway could have an antiatherogenic function, it may also promote the accumulation of $C E$ in foam cell-forming VLDL or chylomicron remnants $(2,3)$. Thus, in circumstances where there is impaired clearance of remnants (e.g., in human dysbetalipoproteinemia), the plasma CE transfer pathway may indirectly contribute to atherogenesis.

Efforts to understand the function and regulation of CETP have led to the purification of a $M_{\mathrm{r}} 74,000$ protein (4) from human plasma and the production of MAbs to the CETP that neutralize its $C E$ and triglyceride transfer activities (5). The human CETP cDNA has been isolated and used to determine the sequence and expression of the mRNA (6). The cDNA hybridizes to a 1.9-kb transcript in human liver and small intestine, apparently the two major sources of apoprotein synthesis in humans, given the large size of these organs. However, comparable or larger concentrations of CETP mRNA were also found in human adrenal gland and spleen (6). Recently, the cloning and sequencing of the rabbit CETP cDNA identified a highly homologous $2.2-\mathrm{kb}$ mRNA that was found in liver but not in other tissues (7).

At present, little is known about the regulation of plasma CETP activity or mass levels. Increased CE transfer activity was found in hypercholesterolemic plasma obtained from cholesterol-fed rabbits $(3,8)$. Alterations in CE transfer activity have been documented in a variety of nutritional states, and during pregnancy (9) or drug therapy (10). However, activity measurements are influenced by factors such as inhibitors (11) and cannot be equated with CETP mass. The recent development of MAbs to CETP (5) and the availability of a cDNA (6) now permit an understanding of CETP on a molecular level.

The aims of the present study were $(a)$ to determine if previously documented changes in activity $(3,8)$ were due to changes in CETP mass, and $(b)$ to measure CETP mRNA changes in response to the atherogenic diet. The changes in CETP mass have been measured by MAb-based RIA, and the human CETP cDNA probe has been used to assess the levels of CETP mRNA in rabbit liver and peripheral tissues. The results show an increase in plasma CETP mass and also a corresponding increase in CETP mRNA in rabbit liver, and suggest that the CETP gene may be subject to dietary regulation.

\section{Methods}

\section{Animals}

Male New Zealand white rabbits weighing $2.5-3 \mathrm{~kg}$ were used in all experiments. All animals were housed individually and had free access to water. Experiments were performed on three different groups of rabbits. 
1-mo cholesterol feeding study. 10 rabbits were fed the high cholesterol diet (rabbit chow supplemented with $0.5 \%$ cholesterol and $10 \%$ corn oil), and 8 rabbits were fed the control diet (standard milled rabbit chow) for 1 mo before killing. Blood was obtained in heparinized tubes from the ear vein, and the plasma separated and frozen at $-70^{\circ} \mathrm{C}$. Organs were removed, frozen immediately in liquid $\mathrm{N}_{2}$, and stored at $-70^{\circ} \mathrm{C}$ until analyzed.

Time-course study. To evaluate the time course of changes in plasma CETP and liver mRNA levels, pairs of rabbits were killed at various times after beginning the high cholesterol diet (at $0,3,5,7,10$, 14 , and $30 \mathrm{~d}$ ).

Lovastatin study. To evaluate the effect of plasma cholesterol levels on CETP, four rabbits fed control chow were given lovastatin and compared with a simultaneous control group of four rabbits receiving no drug. Lovastatin (Merck and Co., Rahway, NJ) was administered orally $(30-60 \mathrm{mg} / \mathrm{kg}$ per $\mathrm{d}$ in drug-impregnated chow, $0.075 \%$ [wt $/ \mathrm{wt}])$ for $7 \mathrm{~d}$ before killing.

\section{Cholesterol measurements}

Total serum cholesterol was assayed enzymatically at $500 \mathrm{~nm}$ using reagents (Sigma Chemical Co., St. Louis, MO) and a modification of the method of Allain et al. (12).

\section{CETP mass measurements}

CETP mass was assayed by solid-phase competitive RIA (13) with the following modifications. Plastic wells were coated overnight with $30 \mathrm{ng}$ purified CETP in $15 \mathrm{mM} \mathrm{Na}_{2} \mathrm{CO}_{3}, 35 \mathrm{mM} \mathrm{NaHCO}$, and $0.02 \%$ $\mathrm{NaN}_{3}$, pH 9.6. A standard plasma pool was prepared from 10 normolipemic human donors, made $2 \mathrm{mM}$ in diethylparanitrophenyl phosphate, and stored in aliquots at $-70^{\circ} \mathrm{C}$. The standard plasma pool was calibrated using purified CETP and had a concentration of $1.8 \mu \mathrm{g} / \mathrm{ml}$. Before assaying standard plasma, all samples were incubated for $1 \mathrm{~h}$ at $37^{\circ} \mathrm{C}$ in an equal volume of $2 \%$ Triton saturation buffer (PBS with $2 \%$ Triton X-100, $1 \%$ BSA, $0.02 \% \mathrm{NaN}_{3}$, and 1 mM EDTA, pH 7.2). MAb TP-2 and antigens were diluted in $1 \%$ Triton saturation buffer to give a final assay concentration of $0.5 \%$ Triton. Before counting, wells were washed three times with $0.5 \%$ Triton saturation buffer.

To ensure that the assay was not influenced by lipoproteins, the $d$ $<1.21 \mathrm{~g} / \mathrm{ml}$ fraction and the $d>1.21 \mathrm{~g} / \mathrm{ml}$ infranatant isolated by ultracentrifugation of plasma for $3 \mathrm{~d}$ at $45,000 \mathrm{rpm}$ in a $50.3 \mathrm{Ti}$ rotor at $10^{\circ} \mathrm{C}$ were each assayed by RIA. This prolonged ultracentrifugation was anticipated to result in complete dissociation of CETP from the lipoprotein fractions, as demonstrated previously (3). The $d<1.21$ $\mathrm{g} / \mathrm{ml}$ fraction gave no displacement in the RIA, while the $d>1.21$ $\mathrm{g} / \mathrm{ml}$ fraction demonstrated a curve parallel to both whole rabbit plasma and the human control pooled plasma. In addition, after correction for volume changes, the displacement curve for the rabbit plasma $d>1.21$ fraction indicated the same CETP concentration as the whole rabbit plasma from which the fraction was isolated. This result showed that the CETP RIA was not artifactually influenced by the markedly increased lipoprotein fraction of the cholesterol-fed rabbits.

\section{RNA extraction and Northern blot analysis}

Total cellular RNA was isolated from various tissues using the lithium chloride/urea extraction method (14). The integrity and quality of all RNA samples was determined by electrophoresis on agarose/borate gels (15) before poly A+ mRNA isolation. Polyadenylated mRNA was isolated from total RNA (16) by batch isolation using oligo (dT)-cellulose (Collaborative Research Inc., Lexington, MA). The resultant mRNA was dissolved in $10 \mathrm{mM}$ Hepes (pH 7.4) and 1 mM EDTA, adjusted to $0.3 \mathrm{M} \mathrm{Na}$ acetate (pH 5.2), reprecipitated with 2.5 vol absolute ethanol at $-20^{\circ} \mathrm{C}$, resuspended in $\mathrm{dH}_{2} \mathrm{O}$ (diethylpyrocarbonate treated), quantitated at $\mathrm{A}_{260 \mathrm{~nm}}$ by spectrophotometry, and used for molecular hybridization. Northern transfer of poly A+ mRNA was performed as outlined by Thomas (17). Briefly, the polyadenylated RNA was denatured with $1 \mathrm{M}$ glyoxal, 50\% dimethyl sulfoxide and separated in $1.2 \%$ agarose. The RNA was transferred to Nytran by diffusion blotting and hybridized with the human cDNA probe at $42^{\circ} \mathrm{C}$ in hybridization solution containing $40 \%$ formamide, $5 \times$ standard saline citrate (SSC), $50 \mathrm{mM}$ sodium phosphate (pH 6.8), $5 \times$ Denhardt's solution, and $200 \mu \mathrm{g} / \mathrm{ml}$ denatured salmon sperm DNA. The human CETP cDNA, clone pCETP.11 (kindly provided by D. Drayna and R. Lawn, Genentech Inc.) contains 1,581 bp of the human gene. Intact poly A+ mRNA was demonstrated by reprobing the filters with chicken $\beta$-actin cDNA. Radiolabeled probes were prepared by the random priming method of Feinberg and Vogelstein (18), yielding sp acts of $1 \times 10^{9} \mathrm{cpm} / \mu \mathrm{g}$. Usually $2-4 \times 10^{6} \mathrm{cpm} / \mathrm{ml}$ were used in hybridizations. Subsequent to hybridization, washing was performed in three changes of $0.5 \times \mathrm{SSC}$ plus $0.1 \% \mathrm{SDS}$ at $55^{\circ} \mathrm{C}$.

\section{CETP MRNA measurements}

The abundance of CETP, actin, apo E, LCAT, and albumin mRNA was determined by quantitative slot blotting (19). The RNA dissolved in $\mathrm{H}_{2} \mathrm{O}$ was denatured at $60^{\circ} \mathrm{C}$ for $10 \mathrm{~min}$, diluted with an equal volume of $20 \times \mathrm{SSC}$, and applied to nitrocellulose membranes prewetted with $10 \times$ SSC using a slot blot apparatus (Schleicher \& Schuell, Inc., Keene, $\mathrm{NH}$ ). The filters were air dried and baked at $80^{\circ} \mathrm{C}$ for $2 \mathrm{~h}$. Slot blots were hybridized stringently in Church and Gilbert hybridization solution (20) at $65^{\circ} \mathrm{C}$ for $18 \mathrm{~h}$. Hybridization with cloned human CETP cDNA was followed by reprobing of the filters with the following cDNA probes: albumin and apo $\mathrm{E}$ derived from rat, chicken $\beta$-actin, and human LCAT. Hybridization of the washed slot blot filters was at $55^{\circ} \mathrm{C}$. Each of the cDNA probes were tested for specific hybridization with rabbit mRNA before slot blot analysis and showed a single band of hybridization of the appropriate size by Northern analysis under the same hybridization conditions. After hybridization filters were washed and subjected to autoradiography at $-70^{\circ} \mathrm{C}$ on XAR-5 film (Eastman Kodak Co., Rochester, NY) using intensifier screens. Filters were stripped with $0.1 \times$ SSC and $0.1 \%$ SDS by boiling for 5-10 min before rehybridization. Autoradiographs of the slot blot hybridizations were quantitated by scanning densitometry. A range of mRNA amounts (2, 4 , and $6 \mu \mathrm{g}$ ) yielded a linear response of hybridization signal with RNA load (see Results). Film exposures of varying duration were quantitated to ensure linearity of film response to the hybridization. All signals from the experimental probes were normalized to control probes such as $\beta$-actin or oligo $(\mathrm{dT})_{15}$. Hybridization of $\left[{ }^{32} \mathrm{P}\right]$ oligo (dT) $)_{15}$ to filter-bound RNA was performed using the method of Harley (21). Relative abundance of actin and CETP mRNA was calculated from the slopes of the hybridization signals.

\section{RNase protection assay}

A CETP cRNA probe (minus strand) was obtained by in vitro transcription from the $\mathrm{T} 3$ promotor of the Bluescript vector containing a cloned 160-bp fragment of the human CETP cDNA, encompassing nucleotides 727-887, which shows extensive homology with the rabbit CETP sequence. RNA solution hybridization was performed as described by Melton et al. (22), with the modification that $T_{2}$ RNase was used for digestion after hybridization. Test total RNA $(50 \mu \mathrm{g})$ from rabbit liver was dissolved in $30 \mu 1$ of $80 \%$ formamide, $40 \mathrm{mM}$ Pipes, 0.4 $\mathrm{M} \mathrm{NaCl}$, and $1 \mathrm{mM}$ EDTA, pH 6.4, containing $1 \times 10^{5} \mathrm{cpm}$ uridine ${ }^{32} \mathrm{P}$-labeled RNA probe (sp act $4-6 \times 10^{8} \mathrm{cpm} / \mu \mathrm{g}$ ). After denaturation at $85^{\circ} \mathrm{C}$ for $5 \mathrm{~min}$ the mix was incubated overnight for $16 \mathrm{~h}$ at $48^{\circ} \mathrm{C}$. The next day samples were incubated for $2 \mathrm{~h}$ at $30^{\circ} \mathrm{C}$ with $350 \mu \mathrm{l}$ buffer containing $50 \mathrm{mM} \mathrm{Na}$ acetate, $0.1 \mathrm{M} \mathrm{NaCl}, 2 \mathrm{mM}$ EDTA, pH 5.0, and RNase $T_{2}$ at a final concentration of $60 \mathrm{U} / \mathrm{ml}$. The reaction was extracted with phenol/chloroform and the [ $\left.{ }^{32} \mathrm{P}\right]$ RNA-RNA hybrid precipitated with carrier tRNA and ethanol. The precipitate was washed with $70 \% \mathrm{EtOH}$ and analyzed on a $6 \%$ polyacrylamide-urea sequencing gel.

The protected fragment was visualized by autoradiography and quantitated from Cerenkov radiation of cut out bands. Complete protection of the probe region homologous to human CETP mRNA yielded a 160-nucleotide fragment as shown in Fig. 7. In control digestions the 234-nucleotide probe (including Bluescript vector sequence) was completely eliminated by digestion with $T_{2}$ RNase in the presence 
of $50 \mu \mathrm{g}$ yeast RNA. The CETP probe is therefore a suitable reagent for the quantitation of CETP mRNA by RNase protection.

\section{Statistics}

Results are given as mean \pm SEM values, and the significance of the differences of mean values is assessed by $t$ test. Two-way analysis of variance and simple correlation analysis were performed using a standard software package.

\section{Results}

CETP mass measurements in rabbit plasma. A competitive solid-phase RIA using the human CETP MAb TP-2 (5) was used to measure CETP mass in rabbit plasma. It was anticipated that rabbit CETP would be well recognized by TP-2 since the sequence of rabbit CETP is almost identical to human CETP in the region of the epitope (7). To validate the assay for rabbit CETP, the displacement curves of control and cholesterol-fed rabbit plasma samples were compared with a standard human plasma pool of known CETP mass. Normolipemic and hypercholesterolemic rabbit plasmas (data points represented by circles and squares) produced displacement curves that were parallel to the standard human plasma pool $(X$ 's; Fig. 1$)$ in the RIA. The curve for undiluted cholesterolfed rabbit plasma was markedly displaced from the standard curve, indicating a higher mass of CETP (Fig. 1, open squares). Subsequent assays of the plasma from cholesterol-fed rabbits were performed at a 1:10 dilution (solid squares), which also gave a displacement curve parallel to the human control. Other experiments showed that the markedly increased lipoprotein fraction in the plasma of cholesterol-fed rabbits did not interfere in the assay (see Methods). These preliminary experiments showed that the RIA was suitable for quantitation of CETP in rabbit plasma, and suggested a pronounced increase in mass of CETP in cholesterol-fed rabbit plasma compared with control.

The RIA was then used to evaluate the levels of CETP in plasma of 10 cholesterol-fed and 8 control animals. The mean plasma cholesterol levels in rabbits fed cholesterol for $30 \mathrm{~d}$ was $1,539 \pm 238.3 \mathrm{mg} / \mathrm{dl}$, compared with $42.13 \pm 8.45 \mathrm{mg} / \mathrm{dl}$ for rabbits fed the chow diet for the same period. The RIA for CETP revealed that cholesterol feeding increased CETP plasma levels approximately threefold $(P<0.001)$ in the hy-

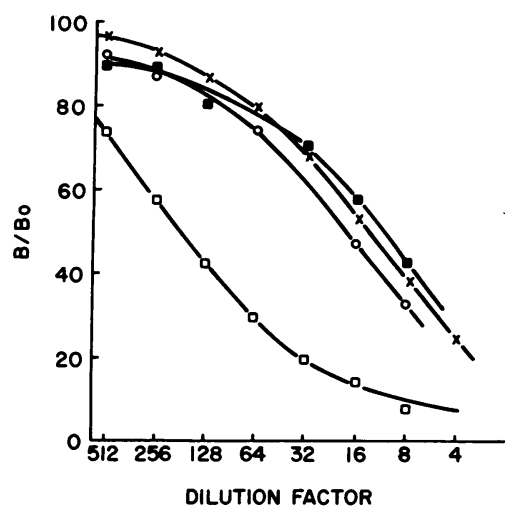

Figure 1. RIA of plasma CETP in control and cholesterol-fed rabbits. Plasma from a rabbit fed either control chow (0) or chow supplemented with $10 \%$ corn oil and $0.5 \%$ cholesterol (ㅁ) or a 1:10 dilution, (ロ) was assayed as described in Methods. Results are expressed as percent of maximal binding (no plasma present) at each

dilution $\left(B / B_{0}\right)$. The standard curve $(X)$ used for the determination of mass in the assay included 1:4 to 1:1,000 dilutions of a human plasma pool prepared from 10 normolipidemic donors and calibrated using purified CETP. percholesterolemic rabbits $(12.45 \pm 0.82 \mu \mathrm{g} / \mathrm{ml})$ compared with controls $(3.86 \pm 0.38 \mu \mathrm{g} / \mathrm{ml})$.

CETP MRNA levels in rabbit liver. To investigate the mechanism of the increase in plasma CETP mass we measured the relative abundance of CETP mRNA in livers of cholesterol-fed and control rabbits. Initially, cross-hybridization of the human CETP cDNA probe with mRNA from rabbit liver was assessed by Northern blot analysis. Poly A+ mRNA prepared from either human spleen (Fig. $2 A$ ) (the richest source of human CETP mRNA [6]), control rabbit liver (Fig. 2 B), or cholesterol-fed rabbit liver (Fig. $2 C$ ) was hybridized with a ${ }^{32}$ P-labeled human CETP cDNA probe. The human CETP mRNA appears as a single transcript of $1.9 \mathrm{~kb}$, while the rabbit liver CETP mRNA was slightly larger, $2.2 \mathrm{~kb}$, as reported (6, 7). These results showed that the human CETP cDNA probe could be used specifically to measure rabbit CETP mRNA. Cholesterol feeding of the rabbits resulted in a two- to threefold increase in abundance of the 2.2-kb CETP mRNA (Fig. $2 C$ ). Similar results were obtained in three separate Northern blot analyses.

Quantitation of CETP MRNA levels in 1-mo cholesterol feeding study. Using conditions that gave a specific signal for the CETP mRNA (see Fig. 2), slot blot hybridization was used to analyze samples from larger numbers of animals. Poly A+ RNA was extracted from 8 control and 10 cholesterol-fed rabbit livers, pooled, and slot blotted, and the filters were probed with ${ }^{32} \mathrm{P}$-labeled CETP cDNA. There was a linear response of the hybridization signal with increasing amounts of RNA applied to the slot blot (Fig. 3). As determined from the difference in the slopes $(P<0.001)$, there was a 2.6 -fold increase in liver CETP mRNA in cholesterol-fed rabbits compared with

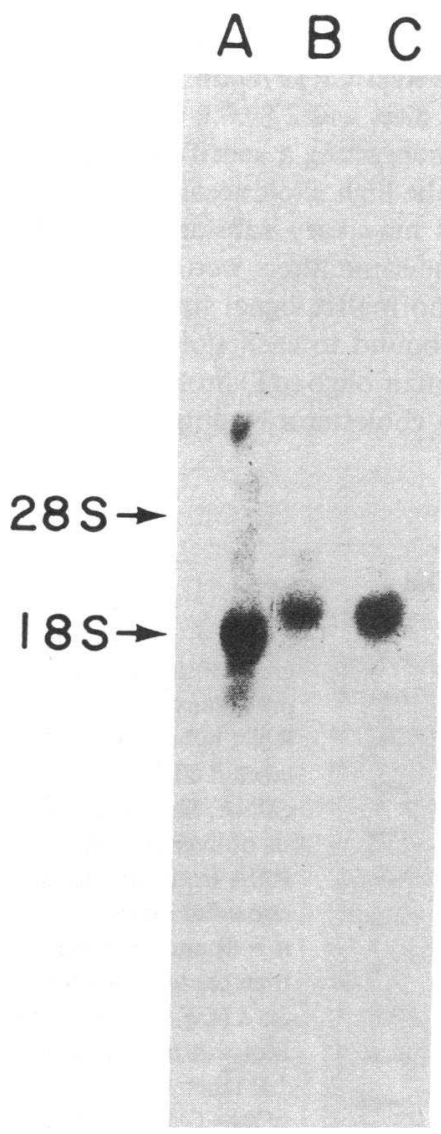

Figure 2. Northern blot analysis of human and rabbit mRNA. Polyadenylated mRNA was isolated as described in Methods. $5 \mu \mathrm{g}$ of RNA from either human spleen $(A)$, control rabbit liver $(B)$, or cholesterol-fed rabbit liver $(C)$ was loaded on a glyoxal/agarose gel, transferred to Nytran, and hybridized to the ${ }^{32}$ P-labeled human CETP cDNA. 


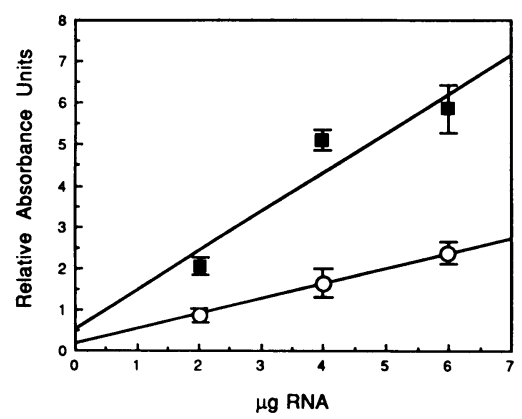

Figure 3. Dose response of slot blot for CETP mRNA. Total RNA was extracted by the $\mathrm{LiCl}_{2}$ /urea method from livers of nine rabbits fed a high-cholesterol diet for $30 \mathrm{~d}$ and nine control animals. Poly A+ mRNA was prepared and blotted as described under Methods. The figure shows a linear plot of a slot blot containing increasing amounts of rabbit liver mRNA hybridized to a ${ }^{32} \mathrm{P}$-labeled cDNA to human CETP. The points shown represent the means \pm SEM of three control pools $(\mathrm{O}$, three animals each) or three cholesterol-fed pools ( $\mathrm{n}$, three animals each) of poly A+ RNA applied to the slot blot as increasing dosage $(2,4$, and $6 \mu \mathrm{g})$.

controls. Further analysis of individual samples was performed at a single RNA concentration of $5 \mu \mathrm{g}$.

The autoradiogram of a slot blot probed with ${ }^{32} \mathrm{P}$-labeled CETP cDNA, comparing individual liver mRNA samples from 10 cholesterol-fed to 8 control rabbits is shown in Fig. 4 $A$. Despite some variability among animals, the specific CETP hybridization signal was noticeably increased in the majority of the hypercholesterolemic rabbits compared with the controls. The CETP mRNA signal was increased $(P<0.01)$ from $1.54 \pm 0.20$ arbitrary absorbance units in control rabbit liver to $4.33 \pm 0.60$ arbitrary absorbance units in cholesterol-fed rabbit livers. Rehybridization of the same blots with chicken $\beta$-actin cDNA probe showed that liver $\beta$-actin mRNA abundance was unaltered $(P>0.5)$ in the rabbits fed high cholesterol diets $(1.1 \pm 0.13$ relative units) when compared with the controls $(1.33 \pm 0.17$ relative units). The liver CETP/actin mRNA ratio in rabbits fed high cholesterol diets was $2.8 \pm 0.6$ times that of controls $(P \leq 0.05$ by $t$ test), suggesting a specific increase in CETP mRNA in response to the high cholesterol diet.

Since actin mRNA levels may vary substantially under certain conditions $(23,24)$, the same filters were also hybridized with $\left[{ }^{32} \mathrm{P}\right]$ oligo $(\mathrm{dT})_{15}$ to normalize signal strength for the amount of poly A+ mRNA bound to each slot. The results were identical using either actin or oligo (dT) probes, i.e., there was no change in signal with cholesterol feeding. Hybridiza-

A

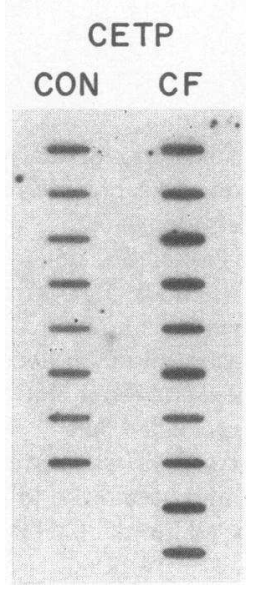

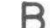

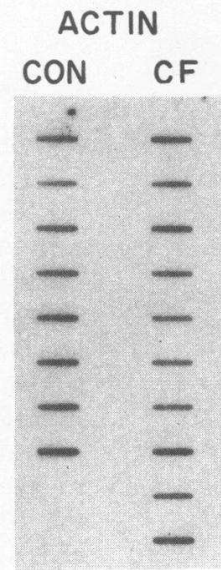

Figure 4. Autoradiogram of slot blot of polyadenylated liver RNA hybridized to ${ }^{32} \mathrm{P}$ labeled CETP and actin cDNA. Slot blot analysis of liver poly $\mathrm{A}+$ RNA from individual chow-fed rabbits $(C O N$; $n=8$ ) and rabbits fed a high cholesterol diet for $30 \mathrm{~d}(C F ; n=10)$. The blot was probed with $\operatorname{cDNA}(A)$ or $\beta$-actin $(B)$. ${ }^{32}$ P-labeled CETP tion of liver mRNA samples with cDNA probes to albumin, apo E, and LCAT demonstrated that the abundance of these mRNAs was unaltered by the high cholesterol diet (not shown). These observations indicate that the increase in CETP mRNA is not a general response of liver proteins or apolipoproteins to the high cholesterol diet.

Tissue distribution of CETP $M R N A$ with cholesterol feeding. Slot blot hybridization of poly A+ RNA from different tissues (Fig. 5) confirms that the liver is the major site of synthesis of CETP mRNA in the chow-fed rabbit, as recently reported (7). Liver CETP mRNA levels were induced about threefold with cholesterol feeding as expected. However, the other tissues gave only a faint signal, close to the limit of detection, or no signal, in both control and cholesterol-rich diets (Fig. $5 \mathrm{~A}$ ). Poly A+ mRNA from spleen and heart, which gave faint nonspecific hybridization signals by slot blot analysis, failed to demonstrate any specific signals by Northern blot analysis, even at higher levels of RNA than those used in slot blot analysis (data not shown). [ $\left.{ }^{32} \mathrm{P}\right]$ Oligo (dT) hybridization of the washed slot blot filter showed that similar amounts of poly A+ mRNA had been bound to the nitrocellulose for the different tissues (Fig. $5 \mathrm{~B}$ ). Thus, in contrast to human CETP mRNA, which is found in liver and also in the small intestine, adrenal, and spleen (6), rabbit CETP mRNA in both control and cholesterol-fed rabbits is restricted to the liver.

Relationship of liver CETP $M R N A$ and plasma CETP mass. The RIA values for the 1-mo cholesterol feeding study were related to the relative mass of CETP mRNA for the 10 individual cholesterol-fed rabbits and 8 controls (Fig. 6). Regression analysis of the data revealed that plasma CETP mass and liver CETP mRNA levels were significantly correlated with an $r$ value of 0.71 ( $P \leq 0.005$ by $\mathrm{F}$ test). However, inspection of the data (Fig. 6) reveals that the regression line is heavily influenced by the clustering of low values in the chowfed animals, and there does not appear to be a significant correlation between CETP mass and mRNA within each group. Thus, the data suggest that the increase in CETP mRNA is in part responsible for the increase in CETP mass in cholesterol-fed animals, but that other factors also contribute to variability in CETP levels.

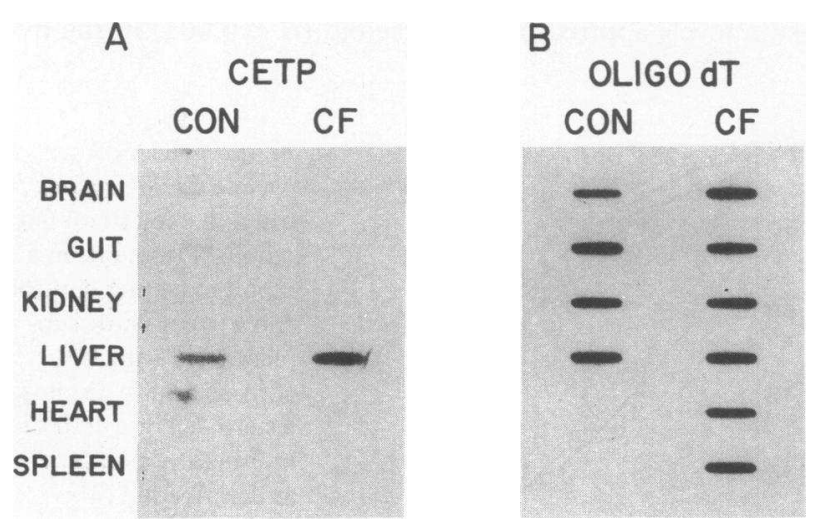

Figure 5. Tissue distribution of CETP mRNA in control vs. cholesterol-fed rabbits. Pooled rabbit poly A+ mRNA $(5 \mu \mathrm{g})$ isolated from various tissues of rabbits fed cholesterol-rich $(C F ; n=4)$ or control diets $(C ; n=2)$ for $30 \mathrm{~d}$ was subjected to slot blot analysis and hybridized with ${ }^{32} \mathrm{P}$-labeled CETP $\mathrm{CDNA}(A)$ using the conditions described in Methods. Rehybridization with ${ }^{32} \mathrm{P}$-labeled oligo- $(\mathrm{dT})_{15}$ is shown in $B$. 


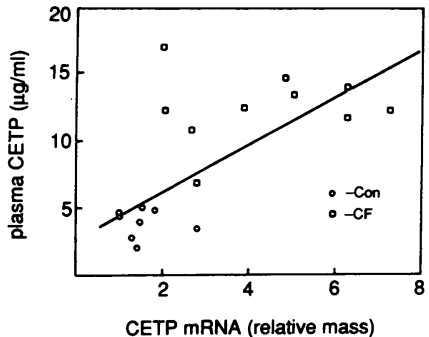

Time course of changes in CETP MRNA. To document the temporal changes in liver CETP mRNA, an RNase protection-solution hybridization assay was developed (see Methods). Such assays are more sensitive and precise than Northern or slot blots and can be performed on total RNA. The RNase digestion resulted in a protected fragment of the expected size (Fig. 7), which was quantitated. The time course of changes in liver CETP mRNA and of plasma cholesterol are shown in Fig. 8. Each point represents the mean \pm SEM value (of four separate assays performed on two rabbits killed at each time point). The data indicate an increase in CETP mRNA, detectable at the earliest time point ( $3 \mathrm{~d}, P \leq 0.05$ compared with day 0 ), and gradually increasing to a value 2.9 times the control (day 0) at $30 \mathrm{~d}$.

Lovastatin study. Lovastatin, a hypocholesterolemic compound that inhibits cholesterol biosynthesis, has been shown to lower CETP activity in rabbits (10). Therefore, lovastatin was administered to rabbits for $7 \mathrm{~d}$ to determine if the druginduced hypocholesterolemia was associated with decreased levels of CETP mass, and to further examine the relationship between CETP mass and mRNA levels. Basal levels of cholesterol and CETP mass were measured in pretreatment plasmas of control $(n=4)$ and lovastatin-treated $(n=4)$ animals. To identify the drug-induced changes in plasma cholesterol the values were expressed as percentages of the respective pretreatment (basal) values. No significant changes in either CETP mass or mRNA levels were found with lovastatin treatment despite a decrease in plasma cholesterol to $49.5 \pm 6.02 \%$ ( $P \leq 0.005$ by $t$ test) of basal values in the lovastatin-treated group.

\section{Discussion}

In this study we have documented a pronounced increase in the mass of CETP in hypercholesterolemic rabbit plasma, clearly showing that changes in plasma $\mathrm{CE}$ transfer activity $(3$,

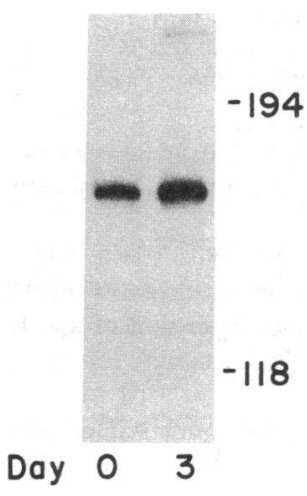

Figure 7. Characterization of rabbit CETP mRNA by RNase protection. The CETP RNA probe corresponding to nucleotides 727-887 of the human cDNA was hybridized to $50 \mu \mathrm{g}$ of RNA from rabbit liver at either day 0 or day 3 on a high cholesterol diet, as described in Methods. The samples were digested with $22 \mathrm{U}$ of $\mathrm{T}_{2} \mathrm{RNase}$ and analyzed by electrophoresis on a $7 \mathrm{M}$ urea, $6 \%$ polyacrylamide gel. The figure indicates the position of radiolabeled $\phi$ X 174/Hae III restriction fragments used as size markers.

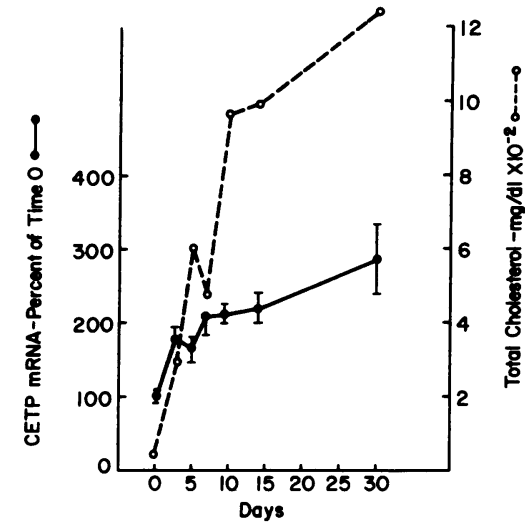

Figure 8. Time course of diet-induced changes in CETP $\mathrm{mRNA}$ and cholesterol levels. Rabbits were fed control diets $(t=0)$ or high cholesterol diets for varying amounts of time and liver CETP mRNA levels (•) and plasma cholesterol (o) were measured in pairs of rabbits killed at each time point. CETP mRNA was measured in total RNA $(50 \mu \mathrm{g})$ by

RNase protection-solution hybridization and each point represents the means \pm SEM of four separate assays performed on a pair of animals. A single protected fragment was observed at each time point.

8) can be due to changes in CETP mass. We also show for the first time changes in CETP mRNA levels, indicating that CETP gene expression may be sensitive to changes in metabolic or nutritional state. As determined by three different approaches (slot and Northern blots of poly A+ RNA and RNase protection-solution hybridization of total RNA) there was a threefold increase in liver CETP mRNA after $30 \mathrm{~d}$ on a high cholesterol, high fat diet. The increase in CETP mRNA is restricted to the liver, begins within $3 \mathrm{~d}$, and represents a specific change in CETP expression rather than a general response of a variety of hepatic mRNAs to the atherogenic diet.

This study was prompted by the finding of increased $\mathrm{CE}$ transfer activity in the plasma of rabbits fed high cholesterol, high fat $(3,8)$, or saturated fat diets $(8)$. Several factors influence CETP activity, such as inhibitory proteins (11) or changes in substrate composition (25). However, the present study documents for the first time an increase in CETP mass by a definitive approach (RIA). The increase in CETP (three times) is sufficient in magnitude to account for a two- to fourfold increase in CETP activity (previously noted in reference 3 ).

An increase in plasma CETP mass could be brought about either by changes in half-life, or by an increase in the synthesis rate of the CETP associated with more abundant CETP mRNA. Increased CETP production (versus catabolism) seems a sufficient explanation for the substantial difference in CETP levels seen in hypercholesterolemia, since the threefold increase in plasma CETP levels as measured by RIA were similar in magnitude to mRNA increases in the rabbit liver. However, there was considerable variability in CETP mRNA levels among cholesterol-fed animals with similar plasma CETP levels (Fig. 6), suggesting that other factors may also influence plasma CETP.

In general, hepatic CETP mRNA levels (7) seem to correlate with variations in plasma CETP mass or activity in different species (26) as well as in the cholesterol-fed rabbit, implying that liver synthesis also plays a major role in explaining species differences in plasma CETP levels and activity. For example, plasma CETP mass (determined by RIA) was approximately two times higher in rabbit plasma than in humans (Fig. 1) and five- to tenfold higher in monkey plasma than in human, in parallel with comparative abundance of CETP liver mRNA for both species (unpublished results). An additional 
source in humans could be extrahepatic synthesis in the small intestine, adrenal gland, or spleen. CETP mRNA could arise from activated lymphocytes or macrophages (27) in the spleen. The CETP mRNA in rabbit liver could be present in hepatocytes or tissue macrophages. However, the absence of detectable CETP mRNA in rabbit spleen (Fig. 5) suggests that macrophages are not likely to be a source of CETP mRNA in the rabbit. The detection of CETP mRNA in isolated hepatocytes (6) and the synthesis of CETP in HepG2 cells $(28,29)$ implies that hepatocytes may be responsible for CETP synthesis within the liver.

Although a large number of genes play important roles in the metabolism of lipoproteins (30), only a limited number of genes have been found to have altered expression in response to dietary changes. For example, in the rabbit fed high cholesterol diets there are marked increases in the plasma levels of apo $\mathrm{E}$ and apo B, but liver mRNA levels for apo $\mathrm{E}$ are unchanged (31) and apo B mRNA levels are actually decreased (32). Differences in apo E and B plasma levels, therefore, are more closely related to differences in their fractional catabolic rates resulting from downregulation of hepatic LDL receptors $(31,32)$. The tandem linkage of the genes for CETP and LCAT at chromosome $16 \mathrm{q} 12-21$ and $16 \mathrm{q} 22$, respectively $(33,34)$, and the related functions of their gene products, suggested to us that the LCAT gene might be coordinately regulated with CETP. However, in rabbit liver, LCAT as well as albumin, actin, and apo E mRNA levels did not change with cholesterol feeding in the present study.

CETP activity has been reported to be altered in a variety of different nutritional states $(3,8)$ and in pregnancy $(9)$, suggesting that CETP gene expression might be sensitive to a variety of dietary, drug, or hormonal stimuli. However, CETP activity measurements are influenced by several factors other than mass, and further studies are required. In the present study we failed to find an effect of lovastatin on CETP mass, in contrast to a decrease in CETP activity previously noted (10). This could be because activity measurements were influenced by some other change (e.g., the decrease in HDL mass [10]).

CETP has been shown to play a significant rate-limiting role in the catabolism of HDL CE in the rabbit, probably promoting the movement of CE from plasma to the liver (35). The major physiological role of CETP may be to transfer the LCAT-derived CE to a pool of triglyceride-rich lipoproteins which undergo rapid catabolism and hepatic uptake by the chylomicron remnant receptor, or get converted into IDL or LDL and taken up by the LDL receptor. Since the HDL CE are derived in part from phospholipids and cholesterol transferred into HDL from the surface of triglyceride-rich lipoproteins during lipolysis (36), the activity of CETP may be seen as a way of returning chemical moieties of surface lipids of triglyceride-rich lipoproteins to the liver. The CETP pathway has the potential to recycle CE to the liver independent of the LDL receptor, and thus may be particularly important when the LDL receptor is downregulated, such as in response to the atherogenic diet. This may provide a potential teleological explanation for the induction of CETP mRNA and mass in response to the atherogenic diet.

\section{Acknowledgments}

We thank Mireille Hogue for her help in some of the immunoassays of rabbit plasma CETP.
This research was supported by National Institutes of Health grants HL-21006, HL-22682, and T-07343, and by a grant from Medical Research Council Canada (PG27).

\section{References}

1. Mahley, R. W., and T. L. Innerarity. 1983. Lipoprotein receptors and cholesterol homeostasis. Biochim. Biophys. Acta. 737:197-222.

2. Tall, A. R. 1986. Plasma lipid transfer proteins. J. Lipid Res. 27:359-365.

3. Tall, A., E. Granot, B. Brocia, I. Tabas, C. Hesler, K. Williams, and M. Denke. 1987. Accelerated transfer of cholesteryl esters in dyslipidemic plasma. Role of cholesteryl ester transfer protein. J. Clin. Invest. 79:1217-1225.

4. Hesler, C. B., T. L. Swenson, and A. R. Tall. 1987. Purification and characterization of a human plasma cholesteryl ester transfer protein. J. Biol. Chem. 262:2275-2282.

5. Hesler, C. B., A. R. Tall, T. L. Swenson, P. K. Weech, Y. L. Marcel, and R. W. Milne. 1988. Monoclonal antibodies to the $M_{\mathrm{r}}$ 74,000 cholesteryl ester transfer protein neutralize all of the cholesteryl ester and triglyceride transfer activities in human plasma. J. Biol. Chem. 263:5020-5023.

6. Drayna, D., A. S. Jarnagin, J. McLean, W. Henzel, W. Kohr, C. Fielding, and R. Lawn. 1987. Cloning and sequencing of human cholesteryl ester transfer protein cDNA. Nature (Lond.). 327:632-634.

7. Nagashima, M., J. W. McLean, and R. M. Lawn. 1988. Cloning and mRNA tissue distribution of rabbit cholesteryl ester transfer protein. J. Lipid Res. 29:1643-1649.

8. Quig, D. W., and D. B. Zilversmit. 1988. Plasma lipid transfer activity in rabbits: effects of dietary hyperlipidemias. Atherosclerosis. 70:263-271.

9. Quig, D. W., and D. B. Zilversmit. 1986. Parallel changes in plasma cholesterol and lipid transfer activity in pregnant rabbits. Proc. Soc. Exp. Biol. Med. 182:386-392.

10. Quig, D. W., and D. B. Zilversmit. 1988. Dissociation between cholesterol secretion and plasma lipid transfer activity in rabbits. FASEB (Fed. Am. Soc. Exp. Biol.) J. 2:2712-2716.

11. Morton, R. E., and D. B. Zilversmit. 1981. A plasma inhibitor of triglyceride and cholesteryl ester transfer activities. J. Biol. Chem. 256:11992-11995.

12. Allain, C. A., L. S. Poon, C. S. G. Chan, W. Richmond, and P. C. Fu. 1974. Enzymatic determination of total serum cholesterol. Clin. Chem. 20:470-475.

13. Marcel, Y. L., H. Czarnecka, R. McPherson, C. Hesler, R. W. Milne, and A. R. Tall. 1988. Cholesteryl ester transfer protein mass in plasma of normolipemic subjects. Arteriosclerosis. 8:593a. (Abstr.)

14. Auffray, C., and F. Rougeon. 1980. Purification of mouse immunoglobulin heavy-chain messenger RNAs from total myeloma tumor RNA. Eur. J. Biochem. 107:303-314.

15. Maniatis, T., E. F. Fritsch, and J. Sambrook. 1982. Molecular Cloning. Cold Spring Harbor Laboratory, Cold Spring Harbor, NY. 75 pp.

16. Aviv, H., and P. Leder. 1972. Purification of biologically active globin messenger RNA by chromatography on oligothymidylic acidcellulose. Proc. Natl. Acad. Sci. USA. 69:1408-1412.

17. Thomas, P. S. 1980. Hybridization of denatured RNA and small DNA fragments transferred to nitrocellulose. Proc. Natl. Acad. Sci. USA. 77:5201-5205.

18. Feinberg, A. P., and B. Vogelstein. 1983. A technique for radiolabeling DNA restriction endonuclease fragments to high specific activity. Anal. Biochem. 132:6-13.

19. Lin-Lee, Y. C., F. T. Kao, P. Cheung, and L. Chan. 1985. Apolipoprotein $\mathrm{E}$ gene mapping and expression: localization of the structural gene to human chromosome 19 and expression of apo $E$ mRNA in lipoprotein and nonlipoprotein-producing tissues. Biochemistry. 24:3751-3756.

20. Church, G. M., and W. Gilbert. 1984. Genomic sequencing. Proc. Natl. Acad. Sci. USA. 81:1991-1995. 
21. Harley, C. B. 1987. Hybridization of oligo (dT) to RNA on nitrocellulose. Gene Anal. Tech. 4:17-22.

22. Melton, D. A., P. A. Krieg, M. R. Rebagliati, T. Maniatis, K. Zinn, and M. R. Green. 1984. Efficient in vitro synthesis of biologically active RNA and RNA hybridization probes from plasmids containing a bacteriophage SP6 promotor. Nucleic Acid Res. 12:70357056.

23. Greenberg, M. E., L. A. Greene, and E. B. Ziff. 1985. Nerve growth factor and epidermal growth factor induce rapid transient changes in proto-oncogene transcription in PC 12 cells. J. Biol. Chem. 260:14101-14110.

24. Blanchard, J.-M., M. Piechaczyk, C. Dani, J.-C. Chambard, A. Franchi, J. Pouyssegur, and P. Jeanteur. 1985. c-myc gene is transcribed at high rate in $\mathrm{G}_{0}$-arrested fibroblasts and is post-transcriptionally regulated in response to growth factors. Nature (Lond.). 317:443445.

25. Morton, R. E. 1988. Free cholesterol is a potent regulator of lipid transfer protein function. J. Biol. Chem. 263:12235-12241.

26. Ha, Y. C., and P. J. Barter. 1982. Differences in plasma cholesteryl ester transfer activity in sixteen vertebrate species. Comp. Biochem. Physiol. 71:265-269.

27. Tollefson, J. H., R. Faust, J. J. Albers, and A. Chait. 1985. Secretion of a lipid transfer protein by human monocyte-derived macrophages. J. Biol. Chem. 260:5887-5890.

28. Swenson, T. L., J. S. Simmons, C. B. Hesler, C. Bisgaier, and A. R. Tall. 1987. Cholesteryl ester transfer protein is secreted by Hep G2 cells and contains asparagine-linked carbohydrate and sialic acid. J. Biol. Chem. 262:16271-16274.
29. Faust, R. A., and J. J. Albers. 1987. Synthesis and secretion of plasma cholesteryl ester transfer protein by human hepatocarcinoma cell line, HepG2. Arteriosclerosis. 7:267-275.

30. Li, W.-H., M. Tanimura, Luo C.-C., S. Datta, and L. Chan. 1988. The apolipoprotein multigene family: biosynthesis, structure function relationships, and evolution. J. Lipid Res. 29:245-265.

31. Chao, Y.-S., T. T. Yamin, G. M. Thompson, and P. A. Kroon. 1984. Tissue-specific expression of genes encoding apolipoprotein $E$ and apolipoprotein A-I in rabbits. J. Biol. Chem. 259:5306-5309.

32. Kroon, P. A., J. A. DeMartino, G. M. Thompson, and Y.-S. Chao. 1986. Molecular cloning of partial cDNAs for rabbit liver apoprotein $B$ and the regulation of its mRNA levels by dietary cholesterol. Proc. Natl. Acad. Sci. USA. 83:5071-5075.

33. Lusis, A. J., S. Zollman, R. S. Sparkes, I. Klisak, T. Mohandas, D. Drayna, and R. M. Lawn. 1987. Assignment of the human gene for cholesteryl ester transfer protein to chromosome 16q12-16q21. Genetics. 1:232-235.

34. Azoulay, M., I. Henry, F. Tata, D. Weil, K. H. Grezeschik, M. E. Chaves, N. McIntyre, R. Williamson, S. E. Humphries, and C. Junien. 1987. The structural gene for lecithin:cholesterol acyl transferase (LCAT) maps to 16q22. Ann. Hum. Genet. 51:129-136.

35. Whitlock, M. E., T. L. Swenson, M. T. Leonard, A. R. Tall, Y. L. Marcel, and R. W. Milne. 1988. Role of cholesteryl ester transfer protein (CETP) in rabbit lipoprotein (LP) metabolism. Arteriosclerosis. 8:593a. (Abstr.)

36. Tall, A. R., P. H. R. Green, R. M. Glickman, and J. W. Riley. 1979. Metabolic fate of chylomicron phospholipids and apoproteins in the rat. J. Clin. Invest. 64:977-989. 